\title{
HIV p24 Antigen
}

National Cancer Institute

\section{Source}

National Cancer Institute. HIV p24 Antigen. NCI Thesaurus. Code C17431.

HIV-p24 antigen, an important core protein of the human immunodeficiency virus, is

encoded by the gag gene. This protein can be detected in serum either in its free form or bound by anti-p24 antibody. Individuals who are HIV-seropositive elicit a significant immune response to p24. Thus, detection of p24 antibodies by ELISA or Western analysis is a screening method utilized to determine the presence of HIV. 